\title{
Pengaruh Promosi, Komunikasi Dan Kepercayaan Terhadap Pengambilan Keputusan Dalam Menjalankan E-Commerce Networking Bussiness Di Kota Padang (Study Kasus Mahasiswa Fakultas Ekonomi Dan Bisnis Jurusan Manajemen Universitas Putra Indonesia YPTK Padang)
}

\author{
Zefriyenni, Emil Salim, Sinta Wahana \\ Universitas Putra Indonesia YPTK, Indonesia \\ E-mail: emil_salim@upiyptk.ac.id
}

\begin{abstract}
Abstrak
Penelitian ini bertujuan untuk mengetahui seberapa besar Pengaruh Promosi, Komunikasi, dan Kepercayaan Terhadap Pengambilan Keputusan Dalam Menjalankan E-commerce Networking Bussiness di Kota Padang. Metode pengumpulan data melalui survei dan mengedarkan kusioner, dengan sampel 89 responden. Metode analisis yang digunakan adalah analisis regresi berganda dengan SPSS versi 2.1. Hasil penelitian yang didapatkan berdasarkan Uji Parsial (Uji t) diperoleh: (a) Promosi memiliki pengaruh sebesar 0,062 terhadap pengambilan keputusan. Maka promosi tidak berpengaruh signifikan dengan $\mathrm{H}_{0}$ diterima dan $\mathrm{H}_{1}$ ditolak.(b) Komunikasi memiliki pengaruh sebesar 0,000 terhadap pengambilan kepuitusan. Maka komunikasi memiliki pengaruh yang signifikan dengan $\mathrm{H}_{0}$ ditolak dan $\mathrm{H}_{2}$ diterima. (c) Kepercayaan memiliki pengaruh sebesar 0,918 terhadap pengambilan keputusan. Maka kepercayaan tidak berpengaruh signifikan dengan $\mathrm{H}_{0}$ diterima dan $\mathrm{H}_{3}$ ditolak. (d) Promosi, komunikasi dan kepercaayaan memiliki pengaruh sebesar 21,321 terhadap pengambilan keputusan. Maka secara bersama-sama Promosi, Komunikasi dan Kepercayaan berpengaruh positif dan signifikan dengan demikian $\mathrm{H}_{0}$ ditolak dan $\mathrm{H}_{4}$ diterima.
\end{abstract}

Kata Kunci : Promosi, Komunikasi, Kepercayaan dan Pengambilan Keputusan.

\section{Pendahuluan}

Kemajuan zaman telah membawa dunia ini pada era globalisasi, yang ditandai dengan kemajuan teknologi yang cukup pesat. Seiring perkeimbangan teknologi ini, terjadi pula perkembangan di banyak bidang salah satunya di bidang transaksi perdagangan yang disebut Electronic commerce (e-commerce). Di era globalisasi seperti sekarang ini, khususnya di Indonesia, padatnya penduduk diiringi semakin kompleksnya kebutuhan dan berbagai aktivitas manusia dalam melakukan mobilitas baik melakukan pekerjaan, sekolah, pariwisata, penelitian maupun traveling, sehingga smartphone perangkat tambahan hingga aksesoris menjadi salah satu kebutuhan penting sehari hari. Keadaan ini yang pada akhirnya menyebabkan semakin ketatnya persaingan antar gerai dan perusahaan yang memproduksi, mendistribusikan dan menjual perangkat dan aksesoris smartphone sebagai eksistensi perusahaan untuk memberikan layanan yang terbaik dalam menarik minat Pelanggan. ( Salim, 2020)

Indonesia tidak pernah ketinggalan dari perkembangan e-commerce. Kejahatan melalui internet dalam berbagai bentuk, baik di Indonesia maupun di belahan dunia lain, masih menjadi ancaman bagi kelangsungan e-commerce. Saat ini pengguna e-commerce berkembang dangan sangat signifikan, berdasarkan hal tersebut maka peluang bisnis e-commerce sangatlah menarik perhatian masyarakat terutama para pengusaha. Dengan kecerdasan berbisnis secara modern, ada banyak investor yang mau berinvestasi ke usaha-usaha mereka melalui e-commerce. Pilihan bisnis ecommerce muncul seiring dengan tumbuhnya kesadaran masyarakat dalam negeri terhadap penggunaan teknologi informasi. Bisnis melalui pemasaran online juga ditunjang oleh infrastruktur jaringan internet yang semakin membaik di Indonesia. 
E-commerce sebetulnya dapat menjadi suatu bisnis yang menjanjikan di Indonesia. Hal ini tak lepas dari potensi berupa jumlah masyarakat yang besar dan adanya jarak fisik yang jauh sehingga e-commerce dapat dimanfaatkan dengan maksimal. Sayangnya, daya beli masyarakat yang masih rendah dan infrastruktur telekomunikasi yang tidak merata di daerah-daerah lainnya membuat ecommerce tidak begitu populer.

Kepercayaan (trust) sangat diperlukan juga dalam menjalankan bisnis ecommerce ini. Banyaknya penipuan di dunia maya, membuat kepercayaan konsumen akan bisnis online masih kurang. Penipuan yang sering terjadi yaitu uang sudah dibayarkan namun produk tidak dikirimkan, atau kualitas produk tidak sesuai dengan gambar yang ditampilkan. Sehingga konsumen lebih sering kecewa jika mereka membeli produk secara online, dan lebih yakin membeli produk offline karena bisa melihat dan memegang langsung produk yang ingin dibelinya.

Tabel 1. Data Penipuan Jual Beli Online Di Sumatra Barat Tahun 2013-2018

\begin{tabular}{llll}
\hline TAHUN & $\begin{array}{l}\text { DATA CYBER } \\
\text { CRIME SUMBAR }\end{array}$ & $\begin{array}{l}\text { DATA PENIPUAN } \\
\text { TRANSAKSI } \\
\text { ONLINE SUMBAR }\end{array}$ & $\begin{array}{l}\text { PERSENTASE } \\
\%\end{array}$ \\
\hline 2013 & 14 & 5 & 36 \\
2014 & 10 & 1 & 10 \\
2015 & 17 & 5 & 29 \\
2016 & 37 & 8 & 22 \\
2017 & 26 & 4 & 15 \\
2018 & 33 & 11 & 33 \\
JUMLAH & 137 & 34 & 145 \\
\hline Sumber : Subdit II Distreskrimsus Polda Sumbar
\end{tabular}

Dari tabel 1 diatas dapat diketahui bahwa pada tahun 2013, terdapat 14 kasus cyber crime di sumatra barat dan 5 kasus penipuan transaksi online. Begitupun di tahun 2014 terdapat 10 kasus cyber crime, dan 1 kasus penipuan transaksi online. Secara berturut-turut pada tahun berikutnya untuk penipuan cyber crime tahun 2015, 2016, 2017, dan 2018 terdapat 17, 37, 26 dan 33 kasus cyber crime. Untuk kasus penipuan transaksi online secara berturut-turut pada tahun 2015, 2016, 2017 dan 2018 terdapat 5, 8, 4 dan 11 kasus. Dan dapat diartikan bahwa kejahatan cyber crime tertinggi berada di tahun 2016 dengan 37 kasus. Dan kejahatan penipuan transaksi online yang tertinggi terdapat di tahun 2018 dengan jumlah 11 kasus.

Menurut Ali Hasan (2013:603) menjelaskan bahwa promosi merupakan proses mengkomunikasikan variabel bauran pemasaran yang sangat penting untuk dilaksanakan oleh perusahaan dalam memasarkan produk. Tujuan utama promosi adalah menginformasikan, mempengaruhi dan membujuk serta mengingatkan pelanggan sasaran tentang pemasaran dan bauran pemasaran.

Berdasarkan penelitian yang dilakukan oleh (Jacky R. Manoppo, 2014) bahwa promosi berpengaruh positif terhadap pengambilan keputusan, sedangkan penelitian yang dilakukan oleh (Aprilia Bayuning sari, 2017) menyatakan bahwa promosi tidak berpengaruh secara signifikan terhadap pengambilan keputusan.

Kepercayaan adalah pernyataan komplek karena individu tidak tau apa motif dam niat lainnya (KremerLing et al, 2010). Kepercayaan dalam konteks pembelian secara online merupakan kesediaan konsumen untuk bergantung pada pihak lain dan rentan terhadap tindakan pihak lain selama proses online shoping dengan harapan bahwa pihak lain akan melakukan praktek yang dapat diterima dan akan dapat memberikan produk dan layanan yang dijanjikan (Mc Kright, 2007 dalam Zendehdel et al, 2011).

Berdasarkan penelitian yang dilakukan oleh (Hartiwi Pratiwi, 2014) menyatakan bahwa kepercayaan berpengaruh positif dan signifikan terhadap pengambilan keputusan. Sedangkan penelitian yang dilakukan oleh (Kartika Ayu ningtiyas, 2018) menyatakan bahwa variabel kepercayaan (trust) berpengaruh tidak signifikan terhadap pengambilan keputusan. 
Berdasarkan penelitian yang dilakukan oleh (Rissa Hanny, 2017) menyatakan bahwa komunikasi berpengaruh positif dan signifikan terhadap pengambilan keputusan.

\section{Landasan Teori \\ Pengambilan Keputusan}

Dalam kehidupan sehari-hari di era teknologi dan komputerisasi saat ini, kita sering mendengar istilah mengenai sistem. Bahkan disadari maupun tidak, kita sering menggunakan atau memanfaatkan layanan yang diberikan oleh sistem tersebut dan kita juga terbantu dengan adanya sistem tersebut. Begitu juga dengan informasi, setiap hari kita selalu mendengar informasi. Informasi ini dapat kita peroleh baik di media cetak seperti koran, majalah buku maupun media elektronik seperti internet, televisi, radio.

\section{Promosi}

Menurut Suparyanto (2015:173), Promosi merupakan salah satu alat bauran pemasaran. Promosi penting keberadaan nya bagi suatu perusahaan. Aktivitas promosi menjadi ujung tembak penerimaan pasar sasaran terhadap produk. Banyak calon konsumen yang tidak mau menerima suatu produk sebelum mendapatkan bauran promosi dari perusahaan.

\section{Komunikasi}

Menurut (Tambunan 2015:255) komunikasi adalah penyampaian informasi atau pesan kepada orang lain. Komunikasi dapat dikatakan efektif, apabila informasi atau pesan yang disampaikan tersebut dapat dipahami dan dimengerti orang lain sehingga ada reaksi (umpan balik) dari orang tersebut untuk menindaklanjuti (menyampaikan) informasi.

\section{Kepercayaan}

Menurut (Faturochman dan Nurjaman, 2018:58) kepercayaan merupakan satu nilai fundamental dalam membangun jalinan interaksi sosal, baik dalam relasi dan interaksi sosial di dunia maya maupun dalam interaksi sosial seca ra langsung. Ketika seseorang salah dalam memegang nilai kepercayaan ini, maka buahnya adalah ketidakpercayaan. Demikian halnya ketika kepercayaan dipegang teguh dan dijanjikan dengan baik, maka buahnya adalah menjadikan orang tersebut sebagai orang yang terpercaya.

\section{Gambar 2.1 Kerangka Fikir}

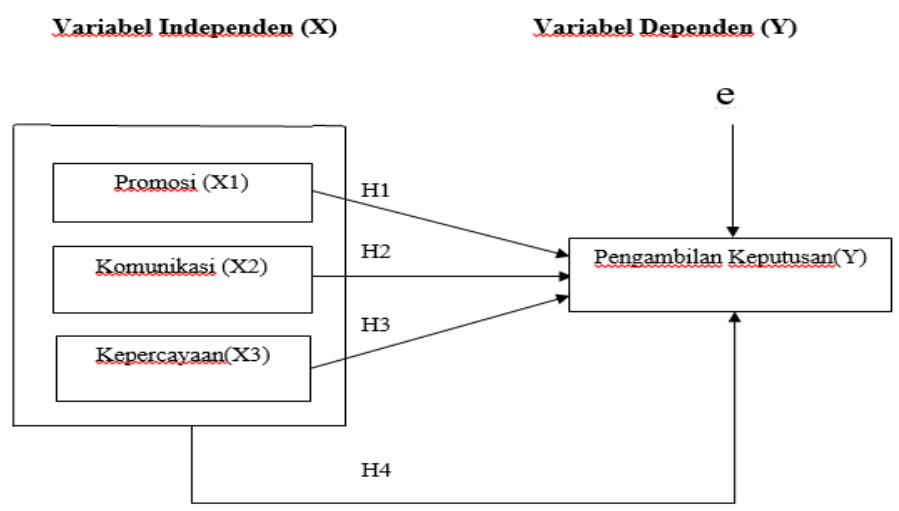

\section{Metodologi Penelitian}

\section{Metode Analisis Data}

Setelah data dikumpulkan, maka data tersebut dapat dianalisis untuk menjawab pertanyaan penelitian, yaitu dengan cara:

\section{Uji Validitas}

Menurut Usman (2013:10), validitas adalah pengujian yang dilakukan untuk mengukur kemampuan atribut-atribut yang digunakan dalam mengukur variabel disebut validitas. Hal ini harus dilakukan mengingat kualitas data ditentukan oleh atribut-atribut yang kita ukur. Bila kita 
menggunakan atribut yang kurang atau tidak tepat, maka nilai variabel yang didapat juga tidak akan tepat.

Statistik deskriptif adalah statistik yang berfungsi untuk mendeskripsikan atau memberi gambaran terhadap obyek yang diteliti melalui data sampel atau populasi sebagaimana adanya, tanpa melakukan analisis dan membuat kesimpulan yang berlaku untuk umum Sugiyono (2009:29).

\section{Analisis Regresi Berganda}

Menurut Siregar (2015:405) regresi linear berganda merupakan pengembangan dari regresi linier sederhana, yaitu sama-sama alat yang dapat digunakan untuk melakukan prediksi permintaan di masa yang akan datang, berdasarkan data masa lalu atau untuk mengetahui pengaruh satu atau lebih variabel bebas (independent) terhadap satu variabel tak bebas (dependent).

Rumus regresi linier berganda:

Keterangan :

$$
Y=a+b_{1} X_{1}+b_{2} X_{2}+b_{3} X_{3+e}
$$

$\begin{array}{ll}\mathrm{Y} & : \text { Pengambilan keputusan } \\ \mathrm{X}_{1} & : \text { Promosi } \\ \mathrm{X}_{2} & : \text { Komunikasi } \\ \mathrm{X}_{3} & : \text { Kepercayaan } \\ \mathrm{A} & : \text { Konstanta } \\ \mathrm{b}_{1} \mathrm{~b}_{2} \mathrm{~b}_{3} & : \text { Koefisien Regresi } \\ \mathrm{e} & : \text { Variabel eror. }\end{array}$

\section{Pengujian Hipotesis}

Uji T

Menguji koefisisen garis regresi digunakan uji t statistik. Uji t digunakan untuk menguji signifikansi konstanta setiap variabel independen akan berpengaruh terhadap variabel dependen. Untuk mengujinya menurut (Sugiyono, 2016: 194) yaitu, dengan rumus sebagai berikut:

$$
t_{\text {hitung }}=\frac{R \sqrt{n-k-1}}{\sqrt{1-r^{2}}}
$$

Keterangan:

$$
\begin{aligned}
& r=\text { Koefisien Determinasi } \\
& r=\text { Koefisien korelasi parsial } \\
& n=\text { Jumlah data }
\end{aligned}
$$

$$
k=\text { Jumlah variabel independent }
$$

Dengan kaidah pengujian sebagai berikut:

$$
\text { 1. } \quad t_{\text {hitung }}>t_{\text {tabel }} \text {, maka tolak Ho artinya signifikan }(\mathrm{a}=5 \%)
$$

2. $\mathrm{t}_{\text {hitung }}<\mathrm{t}_{\text {tabel }}$, maka terima Ho artinya tidak signifikan $(\mathrm{a}=5 \%)$

Perumusan hipotesis nya adalah sebagai berikut:

1. Menentukan rumusan hipotesis:

a. Ho : b1 $=0$, berarti promosi, komunikasi, dan kepercayaan secara parsial tidak mempunyai pengaruh yang signifikan terhadap pengambilan keputusan.

b. Ha : b1 $\neq 0$, berarti promosi, komunikasi, dan kepercayaan secara parsial tidak mempunyai pengaruh yang signifikan terhadap pengambilan keputusan.

2. Menentukan nilai $t_{\text {tabel }}$, pada derajat kebebasan $(d, f)=n-k-1$, dengan $\alpha=5 \%$.

3. Membandingkan $t_{\text {hitung }}$, dengan $t_{\text {tabel }}$.

4. Mengambil keputusan :

a. Bila $t_{\text {hitung }}<\mathrm{t}_{\text {tabel, }}$ maka Ho diterima sedangkan Ha ditolak, artinya menunjukkan promosi, komunikasi, dan kepercayaan secara parsial tidak mempunyai pengaruh yang signifikan terhadap pengambilan keputusan.

b. Bila $t_{\text {hitung }}>t_{\text {tabel }}$, maka Ha diterima sedangkan Ho ditolak, artinya berarti promosi, komunikasi, dan kepercayaan secara parsial mempunyai pengaruh yang signifikan terhadap pengambilan keputusan. 
Uji F

Uji statistik f digunakan untuk menguji seluruh variabel independen (promosi, komunikasi, dan kepercayaan) yang diteliti, mempunyai pengaruh secara bersama-sama terhadap variabel dependen (pengambilan keputusan) Dilakukan dengan membandingkan f-hitung dengan f-tabel. Dengan kriteria sebagai berikut:

Menurut Sugiyono(2016:192) Nilai f-hitung dapat dicari dengan rumus:

$$
F_{\text {hitung }}=\begin{gathered}
\mathbf{R}^{2} / \mathbf{k} \\
\left(1-\mathbf{R}^{2}\right) /(\mathbf{n}-\mathrm{k}-1)
\end{gathered}
$$

Dimana:

$$
\begin{aligned}
& \mathrm{R}=\text { Koefisien korelasi ganda } \\
& \mathrm{k}=\text { Jumlah variabel independen } \\
& \mathrm{n}=\text { Jumlah anggota sampel } \\
& \text { Untuk hasil kesimpulan F-hitung dalam mengambil keputusan jika: }
\end{aligned}
$$

1. F-hitung > f-tabel, maka $\mathrm{H}_{0}$ ditolak dan $\mathrm{H}_{\mathrm{a}}$ diterima $(\mathrm{a}=5 \%)$

2. F-hitung < $\mathrm{f}$-tabel, maka $\mathrm{H}_{0}$ diterima dan $\mathrm{H}_{\mathrm{a}}$ ditolak $(\mathrm{a}=5 \%)$

Perumusan hipotesisnya adalah sebagai berikut:

a. Ho : b1 = b2 = b3 = 0, berarti promosi, komunikasi, dan kepercayaan secara simultan tidak mempunyai pengaruh yang signifikan terhadap pengambilan keputusan.

b. Нa : b1 $\neq \mathrm{b} 2 \neq \mathrm{b} 3=0$, berarti promosi, komunikasi, dan kepercayaan, secara simultan mempunyai pengaruh yang signifikan terhadap pengambilan keputusan.

1. Menentukan $\mathrm{F}_{\text {hitung }}$ pada $\alpha$ atau tingkat signifikan $=5 \%$, dan derajat kebebasan $(\mathrm{d}, \mathrm{f}) \mathrm{df} 1=\mathrm{k}$ dan df $2=n-k-1$

2. Menentukan besarnya $F_{\text {hitung }}$

3. Mengambil keputusan :

a. Bila $F_{\text {hitung }}<\mathrm{F}_{\text {tabel }}$, maka Ho diterima berarti Ha ditolak. Artinya promosi, komunikasi, dan kepercayaan secara simultan tidak mempunyai pengaruh yang signifikan terhadap pengambilan keputusan.

b. Bila $\mathrm{F}_{\text {hitung }}>\mathrm{F}_{\text {tabel }}$, maka Ho ditolak berarti Ha diterima promosi, komunikasi, dan kepercayaan secara simultan mempunyai pengaruh yang signifikan terhadap pengambilan keputusan

\section{Koefisien Determinasi $\left(R^{2}\right)$}

Menurut Riduwan (2014:39) koefisien determinasi berganda $\left(\mathrm{R}^{2}\right)$ atau $\mathrm{R}$ squared berarti secara bersama-sama menyatakan besar kecilnya sumbangan variabel bebas terhadap variabel terikat. R squared berkisar pada angka 0 sampai 1, dengan catatan semakin kecil angka $\mathrm{R}$ squared, semakin lemah pula hubungan kedua atau lebih varibel tersebut. Dengan rumus :

Dimana:

$$
\mathrm{KP}=\mathrm{r}^{2} \mathrm{x} 100 \%
$$

$\mathrm{KP}=$ Nilai koefisien determinasi

$\mathrm{r}=$ Nilai koefisien korelasi

Pengujian koefisien determinasi dibantu dengan program SPSS versi 23.0.

\section{Hasil dan Pembahasan \\ Analisis Regresi Linear Berganda}

Analisis regresi linear berganda digunakan untuk mengetahui pengaruh antara promosi, komunikasi dan kepercayaan terhadap pengambilan keputusan, dimana variabel bebasnya adalah promosi (X1), komunikasi (X2), dan kepercayaan (X3), serta pengambilan keputusan (Y). Berikut uji regresi yang dilakukan. 
Tabel 4.18

Hasil Uji Regresi Linear Berganda Variabel Promosi $\left(\mathbf{X}_{1}\right)$, Komunikasi $\left(\mathbf{X}_{2}\right)$, dan Kepercayaan $\left(\mathbf{X}_{3}\right)$ Terhadap Pengambilan Keputusan $(\mathbf{Y})$

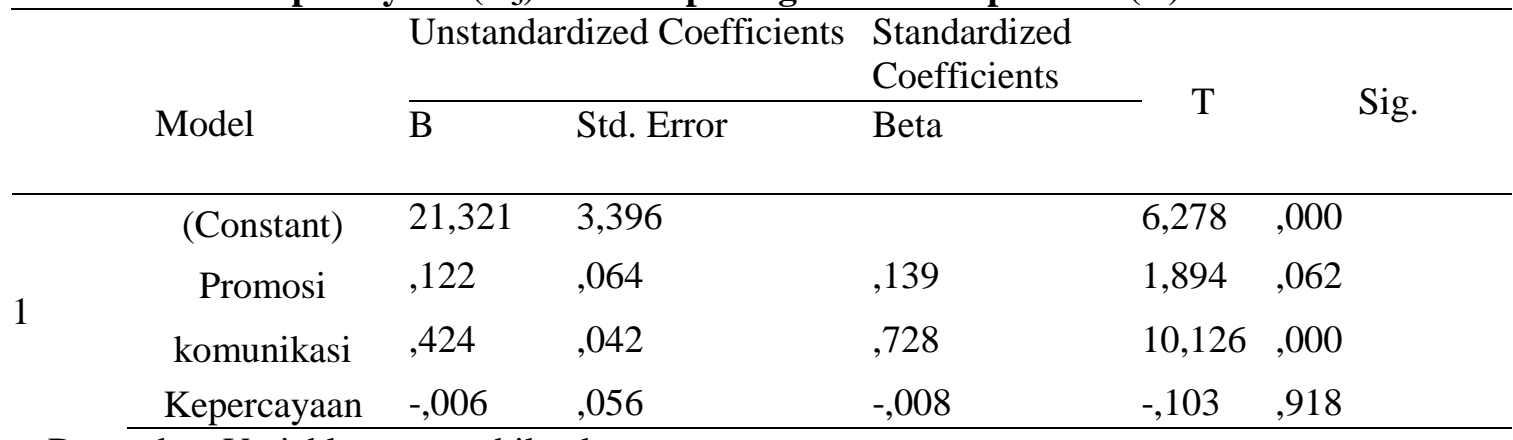

a. Dependent Variable: pengambilan keputusan

Sumber: Output IBMSPSS Statistik 2

Dari tabel 4.13 tersebut dapat disusun persamaan regresi linear berganda sebagai berikut:

$$
\begin{aligned}
& \mathrm{Y}=21,321+0,122 \mathrm{X}_{1}+0,424 \mathrm{X}_{2}-0,006 \mathrm{X}_{3} \\
& +\mathrm{e}
\end{aligned}
$$

Dari persamaan tersebut dapat diambil kesimpulan bahwa:

1. Nilai konstanta menunjukkan 21,321. Apabila nilai variabel independent yaitu promosi, komunikasi dan kepercayaan besarnya 0 maka besar pengambilan keputusan adalah 21,321.

2. Koefisien regresi promosi sebesar 0,122 . Hal ini berarti adanya pengaruh positif promosi terhadap pengambilan keputusan. Apabila promosi meningkat sebesar satu satuan maka pengambilan keputusan akan meningkat 0,122 dalam setiap satuannya dengan asumsi variabel lain tidak mengalami perubahan atau konstanta.

3. Koefisien regresi komunikasi sebesar 0,424. Hal ini berarti adanya pengaruh positif komunikasi terhadap pengambilan keputusan. Apabila promosi meningkat sebesar satu satuan maka pengambilan keputusan akan meningkat 0,424 dalam setiap satuannya dengan asumsi variabel lain tidak mengalami perubahan atau konstanta.

4. Koefisien regresi kepercayaan sebesar -0,006. Hal ini berarti adanya pengaruh negatif kepercayaan terhadap pengambilan keputusan. Apabila kepercayaan meningkat sebesar satu satuan maka pengambilan keputusan akan menurun 0,006 dalam setiap satuannya dengan asumsi variabel lain tidak mengalami perubahan atau konstanta.

\section{Uji Hipotesis}

Uji T

Uji t dimaksud untuk meguji signifikan pengaruh variabel bebas bebas dan terikat secara parsial. Dimana pengujian ini membandingkan antara probabilitas signifikat dengan alpha 0,05. Dari hasil pengujian ini bila probabilitas signifikan lebih kecil dari pada alpha 0,05 maka diperoleh $\mathrm{H}_{0}$ diterima dan $\mathrm{H}_{\mathrm{a}}$ ditolak, berarti tidak ada hubungan. Derajat kebebasan (df) $\mathrm{n}-\mathrm{k}-1$ yaitu 89 $3-1=85$ ( $\mathrm{n}$ adalah responden dan $\mathrm{k}$ adalah jumlah variabel inpependent) sehingga hasil yang diperoleh untuk $\mathrm{t}_{\text {tabel }}$ sebesar 1,988. Dari hasil olah data dapat disajikan pada tabel 4.14 berikut:

Tabel 4.4

Pengujian Hipotetsis Secara Parsial (Uji T) Atas Semua Variabel Independent

\begin{tabular}{llll}
\hline $\begin{array}{l}\text { Faktor } \\
\text { Indepenpendent }\end{array}$ & t-hitung & t-tabel & Signifikan \\
\hline Promosi & 1,894 & 1,988 & 0,062 \\
Komunikasi & 10,126 & 1,988 & 0,000 \\
Kepercayaan & $-0,103$ & 1,988 & 0,918 \\
\hline
\end{tabular}

Sumber: Output IBM SPSS Statistik 21 

berikut:

Berdasarkan pada hasil uji t pada tabel 4.14 maka dapat ditarik kesimpulan sebagai

1. Pengujian hipotesis pertama

$\mathrm{H}_{0}$ :Promosi (X1) tidak berpengaruh signifikan terhadap pengambilan keputusan (Y).

$\mathrm{H}_{1}$ : Promosi (X1) berpengaruh signifikan terhadap pengambilan keputusan (Y).

Variabel promosi memiliki $\mathrm{t}$ hitung 1,894 dengan nilai signifikan 0,062>0,05 maka disimpulkan bahwa $\mathrm{H}_{0}$ diterima dan $\mathrm{H}_{1}$ ditolak. Artinya promosi (X1) berpengaruh tidak signifikan terhadap pengambilan keputusan (Y).

2. Pengujian hipotesis kedua

$\mathrm{H}_{0}$ : Komunikasi (X2) tidak berpengaruh signifikan terhadap pengambilan keputusan (Y).

$\mathrm{H}_{2}$ : Komunikasi (X2) berpengaruh positif dan signifikan terhadap pengambilan Keputusan (Y) Variabel komunikasi memiliki t hitung 10,126 dengan nilai signifikan 0,000<0,05 maka disimpulkan bahwa $\mathrm{H}_{0}$ ditolak dan $\mathrm{H}_{2}$ diterima. Artinya komunikasi (X2) berpengaruh positif dan signifikan terhadap pengambilan keputusan (Y).

3. Pengujian hipotesis ketiga

$\mathrm{H}_{0}$ : Kepercayaan (X3) tidak berpengaruh signifikan terhadap pengambilan keputusan (Y).

$\mathrm{H}_{3}$ : Kepercayaan (X3) berpengaruh signifikan terhadap pengambilan keputusan (Y).

Variabel kepercayaan memiliki t hitung $-0,103$ dengan nilai signifikan 0,918>0,05 maka disimpulkan $\mathrm{H}_{0}$ diterimadan $\mathrm{H}_{3}$ ditolak. Artinya kepercayaan (X3) berpengaruh tidak signifikan Uji F terhadap pengambilan keputusan (Y).

Uji secara bersam-sama (simultan) dilakukan dengna uji F (ANOVA). uji ini digunakan untuk mengetahui apakah variabel independent secara bersama-sama berpengaruh signifikan terhadap variabel dependent atau untuk mengetahui apakah model regresi dapat digunakan untuk memprediksi variabel dependent atau tidak. signifikan berarti hubungan yang terjadi dapat berlaku untuk populasi (dapat digeneralisasikan). Pengujian dilakukan dengan uji $\mathrm{F}$ (ANOVA). Uji $\mathrm{F}$ menggunakan taraf signifikan 0,05 (uji 2 sisi) dengan derajat kebebasan 95\%, alpha $=5 \%$, df 1 (jumlah variabel-1) atau $4-1=3$, dan df $2(\mathrm{n}-\mathrm{k}-1$ ) atau $89-3-1=85$, maka hasil yang diperoleh untuk ftabel sebesar 2,71.

Uji f dimaksud untuk menguji hipotesis dari penelitian yang menyatakan bahwa variabel promosi (X1), komunikasi (X2) dan kepercayaan (X3) mempunyai pengaruh yang signifikan terhadap pengambilan keputusan (Y). Hasil pengujian hipotesis secara simultan dapat dilihat pada tabel 4.15 dibawah ini:

Tabel 4.4

Pengujian Hipotesis Semua Variabel SecaraSimultan

\begin{tabular}{lllllll}
\hline & Model & Sum of Squares Df & Mean Square & F & Sig. \\
\hline & Regression & 566,453 & 3 & 188,818 & 36,866 &, $000^{\mathrm{b}}$ \\
1 & Residual & 435,345 & 85 & 5,122 & & \\
& Total & 1001,798 & 88 & & & \\
\hline
\end{tabular}

a. Dependent Variable: pengambila keputusan

b. Predictors: (Constant), kepercayaan, komunikasi, promosi

Berdasarkan tabel 4.15 di atas dapat dilihat pengujian ini dilakukan dengan cara membandingkan nilai $F_{\text {hitung }}$ dengan $F_{\text {tabel }}$ karena nilai $F_{\text {hitung }}$ lebih besar dari nilai $F_{\text {tabel }}(36,866>$ 2,71). Nilai F 5,122 dengan tingkat signifikan 0,000 lebih kecil dari 5\%. Maka diperoleh $\mathrm{H}_{0}$ dan $\mathrm{H}_{4}$ diterima, yang berarti hal ini dilakukan secara bersama-sama antara promosi, komunikasi, dan kepercayaan berpengaruh positif dan signifikan terhadap pengambilan keputusan.

Untuk lebih jelasnya keempat hipotersis penelitian dapat disimpulkan pada tabel berikut ini: 
Tabel 4.5

Hasil Pengujian Hipotesis Penelitian

\begin{tabular}{|c|c|c|c|c|}
\hline $\begin{array}{l}\text { Hipotesi } \\
\text { s }\end{array}$ & Pernyataan & $\begin{array}{l}\text { Signifik } \\
\text { an }\end{array}$ & Pembanding & Keputusan \\
\hline $\mathrm{H} 1$ & $\begin{array}{lr}\text { Promosi } & \text { berpengaruh } \\
\text { signifikan } & \text { terhadap } \\
\text { pengambilan keputusan }\end{array}$ & 0,062 & 0,05 & Ditolak \\
\hline $\mathrm{H} 2$ & $\begin{array}{l}\text { Komunikasi berpengaruh } \\
\text { positif dan signifikan terhadap } \\
\text { pengambilan keputusan }\end{array}$ & 0,000 & 0,05 & Diterima \\
\hline $\mathrm{H} 3$ & $\begin{array}{lr}\text { kepercayaan } & \text { berpengaruh } \\
\text { signifikan } & \text { terhadap } \\
\text { pengambilan keputusan }\end{array}$ & 0,918 & 0,05 & Ditolak \\
\hline H4 & $\begin{array}{l}\text { promosi, komunikasi dan } \\
\text { kepercayaan berpengaruh } \\
\text { positif dan signifikan terhadap } \\
\text { pengambilan keputusan }\end{array}$ & 0,000 & 0,05 & Diterima \\
\hline
\end{tabular}

Sumber: Data primer yang diolah

\section{Koefisien Determinasi R (Square)}

Analisis Koefisien Determinasi R (square) digunakan untuk mengetahui seberapa besar kontribusi variabel-variabel bebas dalam menjelaskan variabel terikat. Hasil uji koefisien determinasi pada penelitian ini dapat dilihat pada tabel 4.17 berikut ini:

\section{Tabel 4.6}

Koefisien Determinasi Variabel - Variabel Promosi $\left(\mathbf{X}_{1}\right)$, Komunikasi $\left(\mathbf{X}_{2}\right)$, Kepercayaan $\left(\mathbf{X}_{3}\right)$ dan Pengambilan Keputusan (Y)

\begin{tabular}{lllll}
\hline Model & R & R Square & Adjusted R Square & Std. Error of the Estimate \\
\hline 1 & $, 752^{\mathrm{a}}, 565$ &, 550 & 2,263
\end{tabular}

a. Predictors: (Constant), kepercayaan, komunikasi, promosi

\section{Sumber: Data Primer yang diolah}

Dari tabel diatas diperoleh angka R Square sebesar 0,565 atau 56,5\% hal ini menunjukkan bahwa persentase sumbangan variabel independen promosi, komunikasi dan kepercayaan terhadap variabel dependen pengambilan keputusan adalah sebesar 0,550 atau 55\%. Sedangkan sisanya 0,450 atau $45 \%$ adalah sebesar dipengaruhi oleh variabel lain diluar penelitian.

\section{Kesimpulan}

Dari pembahasan pada bab-bab sebelumnya, maka dapat ditarik beberapa kesimpulan sebagai berikut:

1. Promosi tidak berpengaruh signifikan terhadap pengambilan keputusan dalam menjalankan ecommerce networking bussinees di Kota Padang.

2. Komunikasi berpengaruh signifikan terhadap pengambilan keputusan dalam menjalankan ecommerce networking bussinees di Kota Padang.

3. Kepercayaan tidak berpengaruh signifikan terhadap pengambilan keputusan dalam menjalankan e-commerce networking bussinees di Kota Padang.

4. Terdapat pengaruh yang positif dan signifikan antara promosi, komunikasi, dan kepercayaan secara bersama-sama terhadap pengambilan keputusan dalam menjalankan e-commerce networking bussinees di Kota Padang.

5. Koefisien determinasi (R2) sebesar 0,550 artinya artinya variabel promosi, komunikasi dan kepercayaan terhadap pengambilan keputusan berpengaruh sebesar $56,5 \%$ sedangkan sisanya $45 \%$ dipengaruhi oleh variabel lain diluar penelitian ini. 


\section{Daftar Pustaka}

[1] Abdurrahman, H. Nana Herdiana. 2015. Manajemen Strategi Pemasaran. Bandung: CV Pustaka Setia.

[2] Abdillah, Willy. 2018. Metode Penelitian Terpadu Sistem Informasi. Yogyakarta: Andi

[3] Abidin, Yusuf Zainal. 2015 Metode Penelitian Komunikasi. Bandung: CV Pustaka Setia.

[4] Damsar dan Indrayani.2013. Pengantar Sosiologi Ekonomi. Jakarta: Kencana.

[5] Fahmi, Irham. 2014 Perilaku Organisasi. Bandung: Alfabeta.

[6] Faturochman dan Nurjaman, Tabah Aris.2018. Psikologi Relasi Sosial. Yogyakarta: Pustaka Pelajar.

[7] Muhammad, Arni. 2015. Komunikasi Organisasi. Jakarta: Bumi Aksara.

[8] Mulyadi, Deddy. 2015. Perilaku Organisai dan Kepemimpinan Pelayanan. Bandung: Alfabeta.

[9] Nurudin. 2017. Ilmu Komunikasi Ilmiah Dan Populer. Jakarta: Rajawali Pers [10] Ruliana, Poppy. 2016. Komunikasi Organisasi. Jakarta: Rajawali Pers.

[11] E. Salim and M. Neldi, "Membangun Loyalitas Pelanggan melalui Harga dan Kepercayaan dengan Kepuasan Pelanggan sebagai Variabel Mediasi pada Bisnis Smartphone," vol. 13, no. 2, pp. 73-83, 2019.

[12] Siregar, Syofian. 2015. Statitiska Terapan Untuk Perguruan Tinggi. Jakarta: Kencana.

[13] Sunyoto, Danang. 2014. Dasar-Dasar Manajemen Pemasaran. Yogyakarta: CAPS (Center of Academic Publishing Servise).

[14] Suprayanto dan Rosad. 2015. Manajemen Pemasaran. Bogor: In Media.

[15] Tambunan, Toman Sony. 2015. Pemimpin dan Kepeminmpinan. Yogyakarta: Graha Ilmu.

[16] Umar, Husein.2014. Metode Penelitian Untuk Skripsi dan Tesis Bisnis. Jakarta: PT RajaGrafindo Persada.

[17] Usman, Hardius. 2013. Aplikasi Teknik Multivariate Untuk Riset Pemasaran. Jakarta: PT RajaGrafindo Persada.

[18]Widodo. 2017. Metodologi Penelitian. Jakarta: PT RajaGrafindo Persada. 